\title{
Finance for Power Sector Resilience
}

\section{Introduction}

Many countries, cities, utilities, and other energy sector stakeholders are planning for power sector resilience by undertaking vulnerability assessments and developing resilience action plans. Implementing these plans requires identifying and scaling up financing for power sector resilience interventions.

These investments go beyond the basic needs for power generation to support a more secure, reliable, and resilient power system in the face of threats.

Unfortunately, resilience-specific financing sources are limited. This could be in part because it can be challenging to monetize the value of resilience measures relative to an overall investment strategy. The concept of resilience financing is gaining traction, especially as investors recognize that many power sector resilience measures have additional non-resilience based financial benefits. For example, an investment in a well-designed solar minigrid system could support energy access and reduce greenhouse gas emissions while also enabling resilience. Resilience investments are also typically offset by the long-term financial benefits of the investments, averaging a 4:1 benefit-to-cost ratio through minimizing the impacts of threats and decreasing recovery time after negative events (Lloyd's 2018).

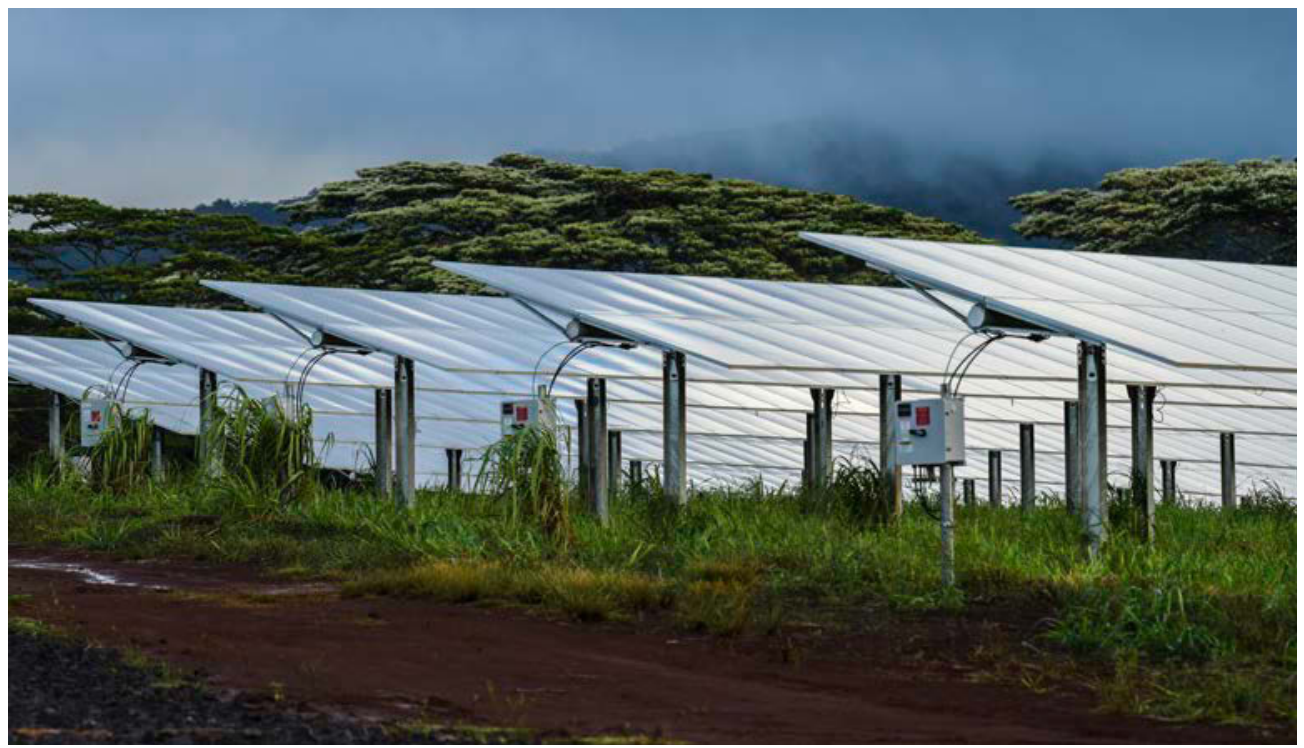

Power sector resilience planning can leverage both traditional financing mechanisms and more nascent, innovative financial instruments. Photo by Dennis Schroeder, NREL 57995

\section{What is Power Sector Resilience?}

The ability to anticipate, prepare for, and adapt to changing conditions and withstand, respond to, and recover rapidly from disruptions to the power sector through adaptable and holistic planning and technical solutions (Hotchkiss 2016)

Resilience finance mechanisms can be established products and tools or innovative financial instruments. Established financing mechanisms, such as bonds, grants, and loans, leverage proven pathways for infrastructure investment by adding additional resilience value to the project. Innovative financial products, which include resilience bonds and green banks, are specifically designed to achieve resilience benefits, but are still nascent.

The most effective resilience finance solutions are location- and contextspecific and can be included in the context of broader resilience planning efforts. The sections below describe several mechanisms to support resilience finance. 


\section{Resilience Finance}

\section{Internal Organizational Budgets}

As resilience planning moves into the mainstream, organizations and governments are increasingly using internal sources, such as annual or capital budgets, to fund resilience actions. By carefully aligning new resilience projects with existing priorities, planners may be able to secure internal funding more quickly than by pursuing outside sources. An advantage is that many internal budgeting sources have well-established timelines and procedures. Aligning projects with internal budgets also enables ownership within the organization or government. In some cases, exploring internal budgeting options can be a prerequisite to securing third-party funding and, thus, can be an important first step in scaling up finance. Planners may be able to match commitments from multiple sources by securing a degree of organizational or governmental buy-in.

\section{Public-Private Partnerships}

Public-private partnerships (PPPs) can play an important role in financing infrastructure projects. Combining private and public funding streams can enable stakeholders to raise more capital than would otherwise be possible. Some benefits of PPPs are that they: decrease the stress on public funds, expedite implementation timeframes, leverage private sector specialty expertise, decrease the risk for the public entity, and have quicker payback times. While PPPs vary significantly in their structure, legal and financial obligations, and complexity, they remain an important option when projects exceed the cost or risk tolerance of a single investor. Innovative partnership models are

Valuing Resilience

Assigning a value to resilience projects can be a challenging task. Some organizations use the value of lost load or customer damage to determine the impact associated with a power outage. ${ }^{2,3}$ For communities and nations it is more challenging to assign a value to resilience, due to the complexity of associated impacts (e.g., gross domestic product [GDP], loss of life, and loss of cultural heritage). Finding a value that resonates with stakeholders in a community may enable investments and finance that considers benefits beyond power reliability and incorporates broader community values.

For a more in-depth look at the challenges and opportunities associated with valuing resilience, see: https://resilient-energy.org/training-and-resources/ fact-sheets/19514_usaid-nrel_valuing_resilience-v7-release.pdf/view

emerging that specifically incorporate resilience considerations. These include the concept of a resilience service company, which functions similarly to an energy service company by covering initial capital costs in exchange for a share of future insurance premium savings (Hotchkiss 2016; Meltzer 2018). PPPs can also support renewable energy projects with resilience benefits. For example, the Africa Finance Corporation used a PPP funding model to construct a $25.5 \mathrm{MW}$ wind farm in Cape Verde, increasing resilience by reducing the island nation's dependence on imported fossil fuels. ${ }^{4}$

\section{Insurance}

The insurance industry is in the early stages of implementing resiliencespecific products, which revalue insurance premiums to incorporate the risk of impacts from future threats. Traditionally, insurance has not been sufficient to cover all disaster recovery costs, and governments have been required to fund uninsured losses. This financial burden hinders economic growth and delays other productive public investments. With increasing frequency and severity of disasters, this gap in coverage is expected to widen. In the future, insurance rate structures could account for proactive improvements to infrastructure that most effectively bolster the resilience of the power sector. One proposed financing mechanism, an insurance-linked loan package, factors in savings from lower insurance premiums that would result from the reduced risk of more resilient infrastructure (Lloyd's 2018). Bangladesh, Mexico, and Thailand, along with over 30 African countries and many island nations, have already invested in preventative insurance measures to aid in disaster recovery and reconstruction (Swiss Re 2016; Hotchkiss 2016).

Another example of an innovative insurance product to support resilience is parametric insurance. This insurance provides coverage that is triggered by a specific threshold - a Category 4 or 5 cyclone or atmospheric pressure levels falling below a certain level, for instance. The payout is predetermined but only

\footnotetext{
2 The Value of Resilience for Distributed Energy Resources: An Overview of Current Analytical Practices, National Association of Regulatory Utility Commissioners, 2019. https://pubs.naruc.org/pub/531AD059-9CC0-BAF6-127B-99BCB5F02198

3 Valuing Resilience in Electricity Systems, Anderson et al., National Renewable Energy Laboratory, 2019. https://www.nrel.gov/docs/fy19osti/74673.pdf 4 See https://www.africafc.org/What-We-Do/Projects/Cabelioca-Wind-Farm-Project.aspx.
} 


\section{Box 1: Hydropower Insurance in Uruguay}

Uruguay has invested in insurance protecting its hydroelectric generation infrastructure from potential losses in low rainfall or drought years.

Hydropower provides up to $90 \%$ of the nation's power, so drought years necessitate costly fuel imports. Now, during drought years, an insurance payout can be triggered to cover the costs of fuel imports.

Read more at https://media.swissre.com/documents/Swiss+Re+case+study+ Closing+the+gap_Uruguay_FINAL.pdf.

available should the specific threshold be measured (Markovic 2018). Because the threshold is pre-determined, parametric insurance payouts can be provided more quickly than many traditional funding avenues (Lloyd's 2018). Box 1 provides an example of an insurance product used in Uruguay, relating to hydropower risks. As noted in the following section, insurance supporting proactive resilience as they pay out after an extreme event. But rebuild in a way that is more resilient to future extreme events. For more information on proposed innovative insurance products for resilience, see Innovative finance for resilient infrastructure (Lloyd's 2018). products are often not well-suited to insurance payouts could be used to
Catastrophe and Resilience Bonds

Catastrophe ("cat") bonds are wellestablished financial mechanisms that help manage the risks from severe natural disasters. Confusingly misnamed "bonds," cat bonds function primarily as a traditional financial risk transfer mechanism. Triggered by an actual disaster event, funds from these bonds can be used to limit the financial losses and economic effects of a disaster.

They are funded by private investors for whom they provide an attractive, high interest rate investment option. The risk to the investors is the loss of their initial investments, should cat bond funds be needed for disaster recovery measures (Swiss Re 2016; Bullock 2017).

Because cat bonds cover insured losses associated with an event, they are paid out after an event, and are therefore poorly suited for proactive, risk-avoidance resilience investments (which are

Some types of resilience financing instruments include public-private partnerships (PPP or P3), insurance, green banks, and multilateral or bilateral development funds. Photo by Dennis Schroeder, NREL 31739

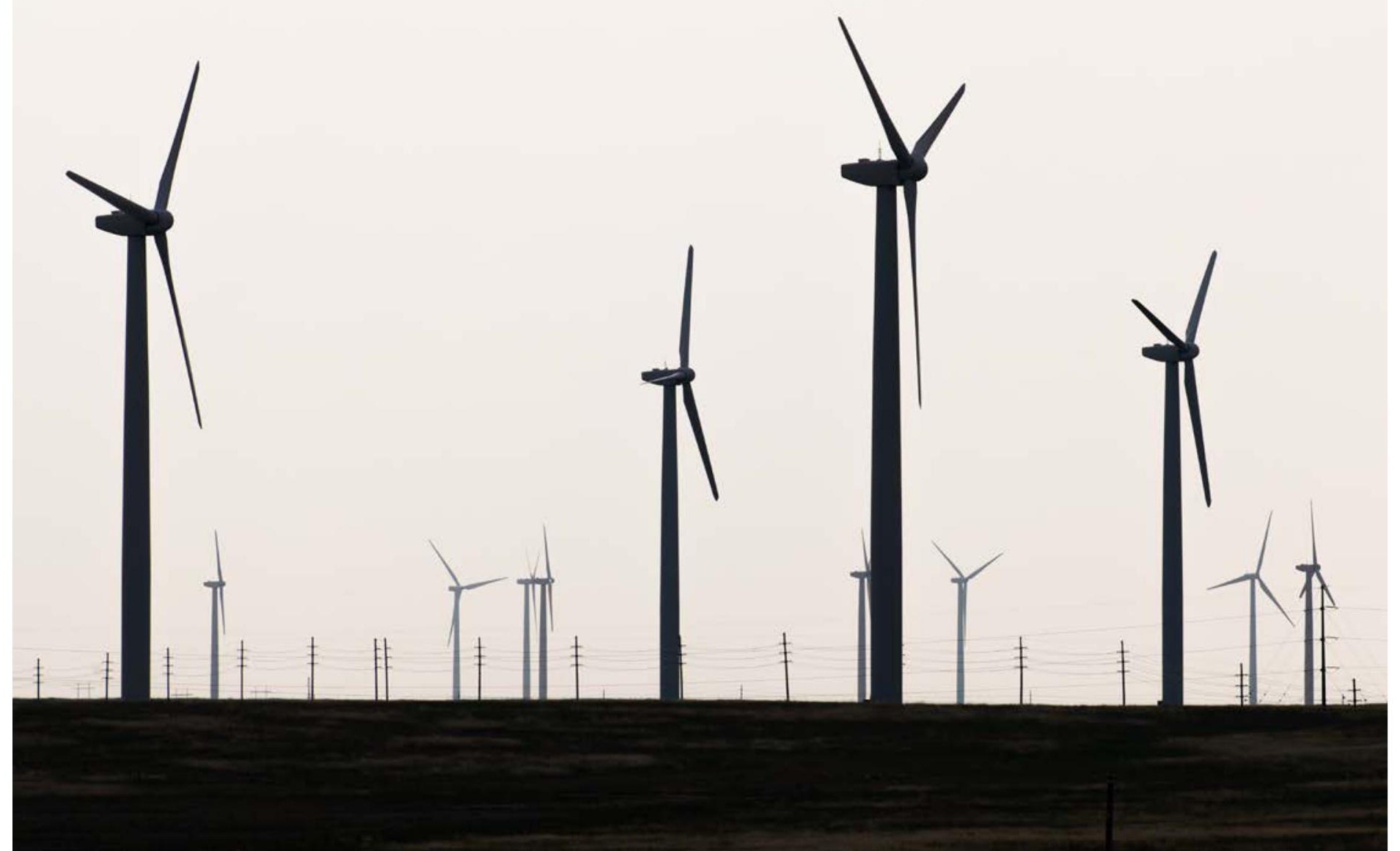


usually the most cost-effective resilience investments). Resilience bonds seek to solve this challenge (Swiss Re 2016).

Resilience bonds build on cat bonds by accounting for the resilience value of an investment and rewarding mitigating measures. This added value is captured as a reduction in insurance premiums. These bonds effectively help governments raise private funding for investments in resilience projects, specifically those aimed at preventing a severe event from becoming a physical or financial disaster (RE Bound 2015). An island community, for example, could use governmental funding from a resilience bond to invest in a battery storage system, which would have immediate resilience benefits by reducing the island's dependency on imported fuel and enabling power delivery quickly post-disaster (assuming the system was not impacted by the disaster).

\section{Bond Financing and Green Bonds}

Bonding is a traditional mechanism for financing large infrastructure projects, such as airports, hospitals, or power plants. Resilience measures can be integrated directly into existing bond structures, such as municipal bonds or other general obligation bonds, through careful project design that includes risk screening. Risk screening uses techniques to assess the vulnerability of an investment to extreme events. ${ }^{5}$ The results of risk screening can enable effective design of measures to enhance resilience. With risk screening as a key input, the type and financial appeal of various bonds will depend on the nature of the organization (i.e., private vs. public), as well as the organization's location and creditworthiness.
Green bonds, a relatively new bond type, require that specific and achievable social or environmental goals be met by the proposed investment. Green bonds require third-party certification and verification, which can add to the complexity of the financing. The World Bank issued a green bond to aid in the development of $150 \mathrm{MW}$ of geothermal power plants in Indonesia, providing a steady, reliable, and domestic generation source (The World Bank 2019). Similarly, Environmental Impact Bonds (EIBs) are a type of payment for performance contract for the achievement of agreed-upon social, environmental, or resilience goals between investors and project owners. EIBs are also well-suited for broad-scale community programs or socially oriented investments, and could be tailored to fit resilience investments in a resilience impact bond (Lloyd's 2018). The market for both green and impact bonds has been growing steadily over the last decade and provides expanding opportunities to support power sector resilience.

\section{Green Banks}

A green bank (sometimes called a green investment bank) secures low-cost capital for financing environmentally friendly projects. Energy resilience banks (ERBs) are green banks specifically aimed at funding resilience initiatives. These banks have been used in energy resilience projects to secure gap financing, or the remaining unmet need after a project has secured traditional public and private capital. ERB financing may be sourced from grants or loanstypically forgivable, longer-term, lowinterest loans-or from small surcharges to the bank's customers. ERBs also seek to leverage funding from other federal, state, or private sources. Box 2 provides an example of green bank financing for distributed energy resources at critical facilities to support resilience. Members of the green bank network can be found here: https://greenbanknetwork.org/ members/(New Jersey Energy Resilience Bank 2017; Tweed 2014; NREL 2016).

Box 2: New Jersey Energy Resilience Bank

New Jersey, a coastal state in the eastern United States, formed the New Jersey Energy Resilience Bank to address infrastructure vulnerabilities after Superstorm Sandy. The state partnered with many organizations to support the most financially effective storm-hardening investments. The bank is focusing on water and wastewater system improvements and investing in solar-powered microgrids and distributed energy resources at high-priority and critical facilities (hospitals, schools, law enforcement centers, and shelters) (New Jersey Energy Resilience Bank 2017).

\section{Public International Climate and Environmental Funds}

Over the last decade, the number of development funds designed to align with multilateral climate commitments and the United Nations Sustainable Development Goals $\left(\mathrm{SDG}^{6}\right)$ has increased significantly. These funds vary significantly in their goals and function, but several have proven to serve as an important conduit for

5 See https://www.worldbank.org/en/news/feature/2014/08/04/world-band-policies-include-screening-climate-risks.

6 For more information on the United Nations Sustainable Development Goals, see https://sustainabledevelopment.un.org/?menu=1300. 
grants or traditional loans for resilience projects, especially in developing countries. Examples of these include the Clean Technology Fund, the Global Environment Facility, and the Green Climate Fund. The Green Climate Fund, for example, provided funding to develop and implement a biomass energy project in Belize, enhancing the nation's resilience and power sector self-sufficiency through a locally produced electricity fuel source.?

Although several international climate funds are available to support projects and actions that enable resilience, power sector planners may not be aware of these funds or how to access them. As a first step, power sector planners can identify and connect with in-country national climate focal points (appointed through the United Nations Framework Convention on Climate Change [UNFCCC]) or National Designated Authorities (NDAs) (appointed through the Green Climate Fund). If a particular nation does not currently have a focal point, one can be nominated (e.g., through the UNFCCC or Green Climate Fund). The focal point can provide information on particular funding options, as well as guidance on the necessary steps to access funds, including relevant stakeholder engagement and proposal submission processes.

Some resources for locating national focal points are:

1. UNFCCC focal points: https:// unfccc.int/process/parties-nonparty-stakeholders/parties/ national-focal-point.
2. Green Climate Fund Guide on NDAs and focal points: https:// www.greenclimate.fund/ documents/20182/194568/ GCF_ELEMENTS_01.pdf/542c161081b4-40df-be62-025cef3d26d8.

While international climate funds can provide opportunities for power sector resilience actions, procuring this funding can take a substantial amount of time, and involved parties can work with national focal points to plan accordingly.

\section{Multilateral Development Banks and Bilateral Development Assistance}

Multilateral development banks (MDBs) provide loans, grants, guarantees, or equity payments for climate-related initiatives, including resilience. The European Bank for Reconstruction and Development (EBRD), for example, issued a loan to a power utility in Tajikistan to upgrade a hydropower facility that introduced innovative climate resilience measures in the face of potential future change in the country's hydrology. For a country heavily dependent on hydropower, this is a valuable example of how climate resilience financing can be incorporated into-and even inform — large energy infrastructure funding. ${ }^{8}$

Other MDBs, such as the World Bank and Asian Development Bank (ADB), lend primarily to sovereign nations, who in turn invest in national or regional projects. These banks often have dedicated resilience or adaptation funding mechanisms that vary in scale, focus, and application process. Jointly, the MDBs publish a summary of their climate financing that provides an up-to-date picture of their investments in resilience. ${ }^{9}$ One example of an MDB resilience fund is the Pilot Progam for Climate Resilience, which is jointly funded by the African Development Bank (AfDB), ADB, Inter-American Development Bank (IADB), World Bank and EBRD, under the broader Climate Investment Funds. While these funds do not have a specific focus on the
Box 3: MDBs and Power Sector Resilience

Bangladesh, which experiences about $40 \%$ of the world's storm surges every year, is particularly vulnerable to power grid outages. The World Bank has helped finance and install solar home systems in over 3 million remote households and shops and is working to install solar minigrids on islands to mitigate the effects of storm surge-related power outages (The World Bank 2017).

After Cyclone lan damaged the electricity network in Tonga in 2014, the Asian Development Bank (ADB) funded a grant to the country to make the electricity system more resilient to extreme weather events and disasters. Read more at https://www.adb.org/projects/48192-001/main\#project-overview.

7 https://www.caribbeanclimate.bz/arundo-donax-renewable-bio-mass-fuel-for-belize-feasibility-study-and-funding-proposal-preparation-an-application-wassubmitted-to-the-project-prepara/

8 https://www.ebrd.com/news/2018/ebrd-and-gcf-invest-in-hydro-power-in-tajikistan.html, https://www.ebrd.com/news/2014/climate-resilience-andhydropower-in-tajikistan.html

9 https://www.worldbank.org/en/news/press-release/2019/06/13/mdb-climate-finance-hit-record-high-of-us431-billion-in-2018 
power sector, they can be used for power sector resilience actions. The International Finance Corporation (IFC), which lends to private entities working to create new marketplaces for services or products in specific countries and regions, also supports resilience measures. For example, the IFC provided finance for the development of a $50 \mathrm{MW}$ wind farm in the Dominican Republic, helping reduce the disasterprone nation's reliance on costly imported fossil fuels and bolstering its power system resilience (IFC 2018). Box 3 provides some examples of MDB support for power sector resilience in Bangladesh and Tonga.

Several bilateral development agencies, such as the U.S. Agency for International Development (USAID), are also providing funding to support power sector resilience. Box 4 presents USAID's work in Ghana to support an IRRP for the power sector.

\section{Organizations to Consider in Exploring Resilience \\ Finance}

1. Africa Finance Corporation (AFC), a public-private institution that provides support for sustainable development of infrastructure in Africa, based in Nigeria: https:// www.africafc.org/home.aspx.

2. African Risk Capacity, providing disaster risk management and financing in Africa: https://www. africanriskcapacity.org/.

3. Agence Française de Développement (AFD), a development finance institute, headquartered in France. The institute has funded renewable energy projects in the Dominican Republic, French Guiana, and Indonesia, and Thailand: https:// www.afd.fr/en

Box 4: Ghana's Integrated Resource and Resilience Plan

Ghana's power system lacked coordinated generation and transmission, had high transmission losses, and was heavily reliant on hydropower and natural gas, which resulted in high electricity rates, service disruptions, and poor power system planning. Using grant money from USAID, the power sector received technical assistance and training and developed an Integrated Resource and Resilience Plan (IRRP). The IRRP will address energy efficiency, demand-side management, generation expansion, microgrid development, and other measures to increase electricity system resilience overall.

Read more at https://ghanalinks.org/documents/20181/0/USAID+Ghana+ Integrated+Resource+and+Resilience+Planning+\%28IRRP\%29+Project+ FY16+Annual+Report/d7137aed-ebfl-469c-80a1-f957672fe3e2?version=1.0

4. Asian Development Bank (ADB), a multilateral development bank, headquartered in the Philippines: https://www.adb.org/.

5. Caribbean Community Climate Change Centre (CCCCC), a public organization that coordinates the Caribbean's response to climate change, headquartered in Belize: https://www.caribbeanclimate.bz/.

6. Corporación Andina de Fomento (CAF), a Latin American regional development bank, headquartered in Venezuela, that has invested in solar, wind, and water power projects: https://www.caf.com/es/ temas/e/energia/.

7. Deutsche Bank Aktiengesellschaft (Deutsche Bank AG), an international investment bank, based in Germany. Through their GET FiT program, they have financed mini-hydroenergy projects in Uganda through PPPs: https://www.db.com/cr/en/ concrete-getfit.htm.

8. ERDB Green Cities: https://www. ebrdgreencities.com
9. Environmental Investment Fund of Namibia (EIF), which supports projects that ensure sustainable use of natural resources: https://www. eif.org.na/.

10. European Bank for Reconstruction and Development (EBRD), a multilateral development bank, headquartered in the United Kingdom: https://www.ebrd.com/ home.

11. Inter-American Development Bank (IDB), a multilateral development bank, headquartered in the United States: https://www.iadb.org/en/ sector/energy/overview

12. Kreditanstalt für Wiederaufbau (KfW), a development finance institute, headquartered in Germany, that issues green bonds: https://www.kfw.de/kfw.de-2.html.

13. Oasis Loss Modelling Framework, an "open source platform for developing, deploying, and executing catastrophe models": https://oasislmf.org/. 
14. United Nations Development Programme (UNDP), headquartered in the United States: https://www.undp.org/ content/undp/en/home.html.

15. United Nations Environment Programme (UNEP), headquartered in Kenya, (https://www. unenvironment.org/) and their Finance Initiative (https://www. unepfi.org/).

16. The World Bank, headquartered in the United States: https://www. worldbank.org/.

17. The Insurance Development Forum, a PPP aimed at using insurance for "understanding risk to create resilient platforms for sustainable growth and human dignity": https://www. insdevforum.org/.

\section{Reading List and Case Studies}

1. Resilience Roadmap: A Collaborative Approach to Multijurisdictional Planning: Hotchkiss, Eliza, Alex Dane, and Connie Komomua. NREL. https://www.nrel.gov/ resilience-planning-roadmap/.

2. Innovative finance for resilient infrastructure. Lloyd's of London, 2018. https://www.lloyds.com/ news-and-risk-insight/risk-reports/ library/understanding-risk/ innovative-finance-for-resilient-infrastructure?utm_source=Launch_ email_trevor\&utm_medium=email\&utm_campaign=emergin grisks_innovative-finance-for-resilient-infrastructure
3. Leveraging Catastrophe Bonds as a mechanism for resilient infrastructure project finance. re:focus partners, 2015. http://www. refocuspartners.com/wp-content/ uploads/2017/02/RE.boundProgram-Report-December-2015. pdf

4. The USD 1.3 trillion disaster protection gap: innovative insurance tools exist to support governments to be better prepared. Swiss Re, 2015. https://www.swissre.com/media/ news-releases/2015/the_USD_13_ trillion_disaster_protection_gap. html

5. Improving the estimated cost of sustained power interruptions to electricity customers. Hamachi La Commare et al., Energy 2018

6. Quantifying and Monetizing Renewable Energy Resiliency. Anderson et al., 2018

7. Climate and Disaster Resilience Financing in Small Island Developing States. OECD, 2016. https://www.gfdrr.org/sites/ default/files/publication/ Final_CDRFinSIDs_20170208_ webversion.pdf

8. Energy Resilience Takes on New Urgency. The World Bank, 2017. https://www.worldbank.org/en/ news/feature/2017/11/10/energyresilience-takes-on-renewedurgency

\section{References}

Bullock, E. P. (2017, Sep. 8). Investors in catastrophe bonds flee Irma fury. Retrieved from Financial Times: https://www.ft.com/content/ c3e7b8cc-9429-11e7-bdfa-eda243196c2c
C2ES. (2017). Financing Resilience. Retrieved from Center for Climate and Energy Solutions: https://www.c2es.org/content/ financing-resilience/

Climate Investment Funds. (2018). Dominica. Retrieved from Climate Investment Funds: https://www.climateinvestmentfunds.org/ country/dominica

Hotchkiss, E. A. (2016). Resilience Roadmap: A Collaborative Approach to Multi-Jurisdictional Planning. Retrieved from https://www.nrel. gov/resilience-planning-roadmap/

IFC. (2018, August). Wind Energy Powers New Possibilities for the Dominican Republic. Retrieved from International Finance Corporation : https://www.ifc.org/wps/wcm/ connect/news_ext_content/ifc_external_ corporate_site/news+and+events/news/ impact-stories/dominican-republic-wind-energy-powers-new-possibilities

Kajitani, Y. (2016). Business Resilience During Power Shortages: A Power Saving Rate Measured by Power Consumption Time Series in Industrial Sector Before and After the Great East Japan Earthquake in 2011. Advances in Time Series Methods and Applications, 239-257. Retrieved from https://link.springer.com/ chapter/10.1007/978-1-4939-6568-7_12

Lloyds of London. Innovative finance for resilient infrastructure. 2018. https:// www.lloyds.com/news-and-risk-insight/ risk-reports/library/society-and-security/ resilient_infrastructure.

Markovic, T. a. (2018). Parametric Insurance: A Tool to Increase Climate Resilience. Retrieved from Marsh \& McLennan Insights: http:// www.mmc.com/insights/publications/2018/ dec/parametric-insurance-tool-toincrease-climate-resilience.htm

Meltzer, J. P. (2018). Blending climate funds to finance low-carbon, climate-resilient infrastructure. Global Economy and Development at Brookings. Retrieved from https://www. brookings.edu/research/blending-climatefunds-to-finance-low-carbon-climateresilient-infrastructure/

New Jersey Energy Resilience Bank. (2017). New Jersey Energy Resilience Bank. Retrieved from https://www.njeda.com/pdfs/ERB/ERBProgram-Guide-8_25_17.aspx 
NREL. (2016). Green Banks. Retrieved from NREL: https://www.nrel.gov/state-localtribal/basics-green-banks.html

RE Bound. (2015). LEVERAGING CATASTROPHE BONDS: As a Mechanism for Resilient Infrastructure Project Finance. Retrieved from http://www.refocuspartners.com/wp-content/uploads/2017/02/RE.bound-ProgramReport-December-2015.pdf

Swiss Re. (2015). Closing the gap:

Drought threat to Uruguay's reliance on

hydropower. Retrieved from https://

media.swissre.com/documents/

Swiss+Re+case+study+Closing+the+ gap_Uruguay_FINAL.pdf

Swiss Re. (2016, 107$)$. The USD 1.3 trillion disaster protection gap: innovative insurance tools exist to support governments to be better prepared. Retrieved from Swiss Re: https://www.swissre.com/media/news-releases/2015/the_USD_13_ trillion_disaster_protection_gap.html

The World Bank. (2017, 11 10).

Energy Resilience Takes on Renewed Urgency. Retrieved from The World Bank: https://www.worldbank. org/en/news/feature/2017/11/10/ energy-resilience-takes-on-renewed-urgency

The World Bank. (2019). Geothermal Clean Energy Investment Project.

Retrieved from The World Bank Projects \& Operations: http://projects.worldbank.org/ P113078/geothermal-clean-energy-investment-project?lang=en\&tab=overview
Tweed, K. (2014). New Jersey Launches \$200M Energy Resilience Bank for Microgrids and Distributed Generation. Retrieved from Greentech Media: https://www.greentechmedia.com/articles/read/new-jersey-launches-200m-energy-resilience-bank-formicrogrids-and-distrib\#gs.JPItWHM

\section{www.resilient-energy.org | www.nrel.gov/usaid-partnership}

Jennifer E. Leisch, Ph.D.

USAID-NREL Partnership Manager

U.S. Agency for International Development Tel: +1-303-913-0103 | Email: jleisch@usaid.gov

\section{Sadie Cox}

Senior Researcher

National Renewable Energy Laboratory

Tel: +1-303-384-7391 | Email: sadie.cox@nrel.gov

This work was authored, in part, by the National Renewable Energy Laboratory (NREL), operated by Alliance for Sustainable Energy, LLC, for the U.S. Department of Energy (DOE) under Contract No. DE-AC36-08GO28308. Funding provided by the United States Agency for International Development (USAID) under Contract No. IAG-17-2050. The views expressed in this under Contract No. IAG-17-2050. The views expressed in this
report do not necessarily represent the views of the DOE or the U.S. Government, or any agency thereof, including USAID.

NREL/TP-7A40-74289 | December 2019

NREL prints on paper that contains recycled content.
The Resilient Energy Platform provides expertly curated resources, training, tools, and technical assistance to enhance power sector resilience. The Resilient Energy Platform is supported by the U.S. Agency for International Development.

The USAID-NREL Partnership addresses critical challenges to scaling up advanced energy systems through global tools and technical assistance, including the Renewable Energy Data Explorer, Greening the Grid, the International Jobs and Economic Development Impacts tool, and the Resilient Energy Platform. More information can be found at: www.nrel.gov/usaid-partnership.

\section{(P) USAID RNREL}

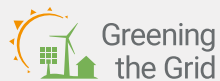

Resilient Energy

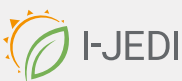

Platform 